\title{
THE CURRENT LITERARY PROCESS AND THE PROBLEM OF POETIC STYLE
}

\author{
Jumagul Rashidovna Suvonova
}

Candidate of Philological Sciences, Associate Professor Samarkand State University Samarkand, Uzbekistan

\section{ABSTRACT}

Reflecting on the current literary process and the problem of poetic style, the author focuses on the work of today's young and talented poet Khosiyat Rustamova. Her work focuses on the socio-political, spiritual, philosophical, symbolic and lyrical world events. Reflects on the fact that poetry is a divine miracle and the peculiarities of its style and the art of poetry, as well as the peculiarities of the poet's work. She also discusses the feelings of the Holy Land, which has become a creative tradition, its love, regional and historical development. Indeed, such issues are one of the most pressing and fundamental problems facing the current literary process. Therefore, the approach to the analysis of such topics, the disclosure of its specific cases, is one of the goals of the article.

KEYWORDS: - Homeland, night, tree, sky, earth, salvation, cry, pan, candle, willow, swallow, vines, freedom, bird, wall, cloak.

\section{INTRODUCTION}

The current literary process in the first twenty years of the XXI century, the well-known poet Khosiyat Rustamova is one of the most prolific poets. Happily, in the works of the poets of the later period, in a sense, both literary and artistic, as well as socio-political and symbolic renewal and change were born. For example, changes in the religious and theological theme in the works of Z. Mirzaeva, changes in the socio-political theme in the works of $\mathrm{H}$. Ahmedova, changes in the spiritual, philosophical and lyrical experience in the works of H. Rustamova are clear examples of the news of this period.

Poet H. Rustamova's 1997 "Iste'dod" under the title
"Osmondagi uy", "Najot" (2003), "Rido" (2004), "Yupanch" (2005), "Devor" (2006), "Avgust" (2008), "Ishg'ol" (2011), "40:0" (2011), "Unutilgan yillar" (2014), "Bebosh bulutlar" (2019). Many of his poems and books of poetry have been translated into Russian, Azeri, Tajik, English, German, Swedish, Dutch, Vietnamese, French, Spanish, Italian, Turkish, and Kazakh. These include "Yarınsız günler" (No more days), in Turkey in 2006, "Qorxunç" (Fear), in Azerbaijan in 2008, and "Anatomy of Love" in Kazakhstan in 2020. Recently, the English-language book "Colorful Tears" was published in London, "Chiều cao của gió" (The height of the wind) in Vietnam, and her book "İki güneş" (Two Sun) in Turkey.

The work of Khosiyat Rustamova, a member of the 
CURRENT RESEARCH JOURNAL OF PHILOLOGICAL SCIENCES 2(9): 123-

133, September 2021

DOI: https://doi.org/10.37547/philological-crjps-02-09-26

ISSN 2767-3758

(C)2021 Master Journals

\section{Crossref do}

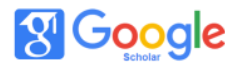

Accepted25 $5^{\text {th }}$ September, 2021 \& Published $30^{\text {th }}$ September, 2021

Writers' Union of Uzbekistan, and her artistic and artistic achievements are of special importance. From kitchen utensils to trees, rain, wind, or even ordinary situations, things can come to life and breathe the breath of time, creating social or emotional coincidences. As the reader visits the poet's creative world, we are sure to put a certain mark on each page, or draw thin lines between the lines of each poem, or write bright ideas as if they were written in a notebook frame along the lines drawn aside. of course. After all, Khosiyat Rustamova's poems are full of coincidences that capture the human mind. Well-known poet Erkin Vahidov says about such poets: "Thousands and millions don't have to read a poet. There are poets who are read by one person at night. The book is under the pillow. This is happiness for a poet. " [2.P.160]. Khasiyat is one of such poets. The question arises: All well-known poets are creating in a rhythmic way, enjoying examples of classical literature, folklore, or a so-called modern way of expressing themselves in a language and style that no one can understand. Why didn't Khasiyat follow them while looking for style?! Because he had a chosen path, a purpose, and a destination. She quietly entered the house and turned to world literature. She studied European culture, language and literature. It's like a poem that starts with "I made my way ...";

Endi ohu faryod botmas yurakka,

So'nggi manzilimni ko'ryapman ayon.

Tirmashib chiqyapman osmon-falakka,

Pinhon qudratimni etib namoyon. [3.P.38].

Meaning:

Now the cry does not sink into the heart,

I can see my last address.

I'm climbing into the sky,

Demonstrating my hidden power.

- she said, moving toward his destination. She began to rise through hard work, reading and studying. And, of course, to show the power of the hidden, to discover herself. Earlier, Russian poets
Marina Tsvetaeva, Anna Akhmatova, Boris Pasternak, A.S. Pushkin turned to Esen's poetry, then to English, French, and German poetry, and then to Turkish, Azeri, and Indian poetry. These researches, as the poet thinks, were just an attempt to show his hidden power.

In poetry, there are various metaphors or artistic expressions of the state of shedding tears, we all observe the intimate states of the poet's experiences. However, Khosiyat Rustamova describes the situation in such a way that as a result, in her poem "In the back seat of the car" tears flow like rebellious children who do not obey the wishes of the poet, violate the rules of the road and run without red lights begin:

Qizil chiroqlarga qilmas rioya,

Mening ko'zlarimdan oqayotgan yosh. [4.P.3].

Meaning:

Does not follow red lights,

Tears well up in my eyes.

- the poet describes the situation in an inner spirit.

"Green lights," "red lights," "double-breasted collar,"

"hands in your pockets," "a cup of coffee," "brown handkerchiefs," "the last matchstick There are speculations that many such expressions, such as, were introduced into the poet's work from Russian or European literature, but this is true. But the poet imposes a new meaning on each of them, and does not force each of them, but pulls them by the collar, pats them on the shoulder, caresses them, turns them into their own words like a child, puts on new clothes, assigns new tasks, and carries new ideas. enters. In this way, he reveals and expands his style, talent and skills.

As he quietly enters the house, he reveals a secret with his creative language without telling anyone. This was a testament to the views of John Galsworthy in a collection of translations by renowned literary scholar Ozod Sharafiddinov entitled "World Writers on Literature". In his article "Creating Character in Literature," she argues, what is creative individuality? In search of an answer to 
CURRENT RESEARCH JOURNAL OF PHILOLOGICAL SCIENCES 2(9): 123-

133, September 2021

DOI: https://doi.org/10.37547/philological-crjps-02-09-26

ISSN 2767-3758

(C)2021 Master Journals

Crossref do

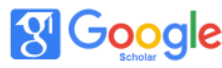

Accepted25 $5^{\text {th }}$ September, 2021 \& Published $30^{\text {th }}$ September, 2021

the question, she thinks of the subconscious: "...everyone is, in our view, like a limmo-lim full of hum - this hum has a subconscious experience, which can also be called a secret storehouse of influences. Collected directly by that person or from the experience of others, seen, heard, tasted, Impressions are gained in a fluid, global, diffused way." [5.P.82]. As Khosiyat Rustamova searches, reads and studies, she confirms this philosophy of the great philosopher John Golsworthy. The poet, who has enriched his subconscious, now begins to use the best words and ideas from it without breaking them:

Qarayman tashqariga derazam oynasidan,

Kiprigimga osilib halinchak uchar jahon.

Yo xudo ertalabdan qanday ulgurdi ekan,

Kir kabi bulutlarni dorga yoyibdi osmon.

Havoning bir ch etidan qushlar o'ynaydi tortib,

Shamol tog'larga chiqib do'pposlaydi qorlarni.

Bir qushcha ham bo'lolmay men o'zimni yo'qotib,

Qolib ketyapman hanuz ortida devorlarning! [4.P.49].

Meaning:

I look out the window,

The world hangs on my lashes and flies away.

Oh, how God got up in the morning,

The sky spread clouds like Cyrus on the tree.

Birds are playing in the air,

The wind blows into the mountains and blows the snow.

I lost myself in not being a bird,

I'm still behind the walls!

The lines used in the above poem, such as "The world hangs on my lashes," "The sky spreads clouds like dirt," "Birds play from one end of the air," "The wind blows snow on the mountains," are the poet's researches. as a result, completely new findings are portrayed as examples of metaphors, that is, analogies. Of course, this fact is also confirmed by the great thinker and poet Mahmud Kashgari. It is no coincidence that Qutadgu bilig says, "Where there is learning, there is greatness, and where there is knowledge, there is greatness." not disclosed. As the poet's views changed, he began to openly express the influence of Russian literature in her work.

Ishingga ketasan - demay xech nima,

Mayli, och ketsang ket-buzmayman pinak.

Meni ham xonamda kutar Marina,

Meni ham xonamda kutar Pasternak. [3. P.12].

Meaning:

You go to work without saying anything,

Well, I don't care if you're hungry.

Marina is waiting for me in my room,

Pasternak is waiting for me in my room.

- says.

Creation is a divine miracle of the spiritual world. Artists who have ascended to the spiritual world express art in a new, unique language and style. That's why they have their own imaginary worlds. That is why they always live in their own mysterious and magical world, with blue skies, fresh air and high dreams. In fact, now he is not following in the footsteps of others, not saying what others say, but creating a unique way and style that is different from the language and style of others. In this way, he begins to express his thoughts in a mysterious and magical language.

Qaysi aql bilan ekdim bu gulni,

Ko'ra bila turib singan tuvakka.[3. P.8].

Meaning:

By what wisdom did I plant this flower,

Deliberately broken pot.

In fact, the sign in these lines seems to be a detail of a vase with a flower. But the fact is that these details have a very hidden meaning. At a glance, not everyone realizes that a flower is depicted as a tree or a person, and a pot as a ground or Motherland. At the same time, the poetess incorporates her childish attitude into these two lines.

Bugun gul qoshida ko'rib bulbulni, Vahima, g'ulg'ula tushar yurakka. [3. P.8].

Meaning:

Today I saw a nightingale under a flower, 
CURRENT RESEARCH JOURNAL OF PHILOLOGICAL SCIENCES 2(9): 123-

133, September 2021

DOI: https://doi.org/10.37547/philological-crjps-02-09-26

ISSN 2767-3758

(C)2021 Master Journals

Crossref do

gil Google

Accepted25 $5^{\text {th }}$ September, 2021 \& Published $30^{\text {th }}$ September, 2021

Panic, heartbreak.

Now, no matter what happens, the sight of a flower that has become like a child and a nightingale perched on a flower in front of her, the very fact that the poet's heart is pounding, intensifies his sense of belonging. After all, there would be no need for panic and fuss if it weren't for the ties to that flower or pot, or the feeling of love and affection for it. In this one line, the poet hides the meaning that the nightingale's consent is not always true and sincere, and points out that she is not deceived by the contradictions of her child in the form of a flower, and that she has a life-threatening path ahead of her.

Nima qilsam ekan?

Ko'ngil to'la mung,

Bir yoqda g'ijimlab turibdi yurak.

Gul esa beparvo o'sar kundan-kun,

Kundan-kun kichrayib boradi tuvak. [3. P.8].

Meaning:

What can I do?

I'm very sad,

My heart is pounding.

And the flower grows carelessly day by day,

The pot is getting smaller day by day.

Thinking about the fate of the flower, its future, its happiness and joy fills the poet's heart with pain. On top of that, her heart is pounding under the pressure of such heavy thoughts. This situation strongly affects the psyche of the poet. Her mood is gloomy, her body and soul are in pain, and his heart is full of difficult questions. But the flower grows carelessly, and the pot shrinks day by day. And these lines usually indicate that the nightingale's consent is not always true and sincere. Even if she is in love, the poet is scratched by a dog, which contains the issues of children, honor and homeland. Of course, when it comes to the love of the nightingale, there are many proverbs, sayings and parables in the Uzbek folklore. This is where her infidelity comes into play. As a teenager growing up in the image of a flower, and as he grows up, the concept of mother and homeland, which looks like a small, broken pot, becomes more and more strange. Through these lines, the poet suggests that as a person grows older, her views will change. In fact, she is saddened by the strange appearance of the Motherland, which has always been humble, sincere and childish. The great philosophical conception of the homeland in the poet's mind becomes a great pain.

Do'kondan boshqa bir gultuvak oldim, Yumshoq bir tuproqdan qorib soldim loy. Bolajon bo'ylaring cho'zilib qoldi, Ishqilib butunmi sen tug'ilgan joy. [3. P.8]. Meaning:

I bought another bouquet from the store, I licked the mud from a soft soil.

Your baby is tall,

Is that where you were born?

Now we come to the part where we talk about the middle ground. In fact, the poet's goal is to say what is in the subconscious warehouse! Of course, if the pot of the flower you planted shrinks or breaks, you can take another flower, add soil and water to it, and transfer the flower to that pot. But what if a flower and a pot are not just flowers and a simple pot ?! What if she is discovering the metaphorical and symbolic meaning of the homeland, the mother, and the growing adolescent ?! Where was she born Who was she born from? Isn't the poet detailing his painful feelings through these flowers and pots, gathering and generalizing all his experiences around these flowers and pots? meaning is a fitting concept that has been discovered. Our poets have created colorful findings and images of these concepts in a symbolic and figurative sense. However, Khosiyat Rustamova finds a comparison of these concepts in such a way that the discovery was able to go through the synthesis of the subconscious spontaneously and simultaneously discover the vital, natural, social and political and artistic content. We can understand this phenomenon by asking, "Is your child's neck 
CURRENT RESEARCH JOURNAL OF PHILOLOGICAL SCIENCES 2(9): 123-

133, September 2021

DOI: https://doi.org/10.37547/philological-crjps-02-09-26

ISSN 2767-3758

(C)2021 Master Journals

\section{Crossref do}

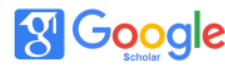

Accepted25 $5^{\text {th }}$ September, 2021 \& Published $30^{\text {th }}$ September, 2021

stretched out and rubbed? Is that where you were born?" After all, she is not only the Motherland, she is talking about every mother and her sense of belonging to the Motherland. Otherwise, the meaning of the place of birth would not have been emphasized with such a subtle gesture. Isn't that true? Isn't each of us a Motherland? Aren't each of us a Motherland, which is compared to the pot of creating and growing several young saplings? As we read the above verses over and over again, it is the poet's original to magnify this true concept of the Homeland, to turn it into a great concept of the Homeland and to harmonize with it, or to create such a symbolic meaning of growth and harmony. We are sure that the goal.

Biz Vatan haqida o'ylamaymiz hech,

Ulg'ayaveramiz kun o'tgan sayin. [3.P.8].

Meaning:

We never think about the homeland,

We are growing day by day.

In this one byte all the experiences of the poet are clarified. When the time comes, we will show how careless we are about our Motherland, its problems, pains and sufferings. Their experiences bring us closer to our eyes as we experience childish indifference to so many things that concern us. It is no secret that due to negligence, carelessness and negligence can cause various injuries and cracks in the chest of our mother. It should also be noted that the purpose, the idea and the meaning behind it, the artistic expression is the skill of the poet's stylistic originality.

Although we witnessed thought, feeling, tone, image, experience, expression, action, situation in the above poem, we actually witnessed the skill of using natural means such as imagery, sociality, art, reality, vitality we are. It is true that we can cite many examples of contemporary Uzbek literature. There are such representatives of modern literature as A. Qutbiddin, B. Ruzimuhammad, Gozal Begim, Aydinniso, who also differ from other artists in their creative world with their language and images.
However, the novelty of Khosiyat Rustamova's creative activity lies in the breadth of her artistic thinking, that is, the breadth of the imaginary world, the fluency and content of her visual style.

Khosiyat Rustamova uses the word in a unique way. She treats the property of the Word as a priceless treasure. This, in turn, creates a world of painful, attractive, genuine spiritual words that belong only to her. And no doubt, with his faith and love, he will inspire others to appreciate, respect and pay attention to the word. That is why in his work, reality always serves a purpose and an idea. Sometimes the branches of a vine sit on a wall or a tree, cross their legs, express the mysterious state of life rich in coincidences, create miraculous images and metaphors from ordinary landscapes and situations, and express their hidden imaginations artistically:

Boqib bog'ning rang-u ro'yiga,

Qovushtirar qo'lini behol.

Gunohini olib bo'yniga

Yer chizgancha turar majnuntol.

Qaldirochlar kelib mo'ltirar,

Topolmasdan og'ochlarini.

Daraxtlarda toklar o'ltirar-

Chalishtirib oyoqlarini. [6. P.26].

Meaning:

Looking at the color of the garden,

It can't move its hand.

It confessed its sin

Willow standing as the ground draws.

Swallows come and go,

Can't find the trees.

There are vines in the trees.

Mix their legs.

Sometimes she turns into a bird in a cage, embarrasses it and asks for something she doesn't have:

Jovdirab qaraysan qafasdan otsam,

Bir hovuch ushoq, don, suv va maysani.

Oldingga tashlayman nimaki topsam-

Ozodlikdan boshqa hamma narsani. - dediradi.[ 3. 
CURRENT RESEARCH JOURNAL OF PHILOLOGICAL SCIENCES 2(9): 123-

133, September 2021

DOI: https://doi.org/10.37547/philological-crjps-02-09-26

ISSN 2767-3758

(C)2021 Master Journals

\section{Crossref do}

\section{Google}

Accepted25th September, 2021 \& Published $30^{\text {th }}$ September, 2021

P.16].

Meaning:

If you shoot me out of the cage,

A handful of oats, grain, water and grass.

I'll throw what I find

Everything except freedom.

In these verses, the poet dwells on FREEDOM, which has been a constant source of dreams and aspirations for all peoples and nations for centuries, and which has become a problem in time and has caused many wars. When he stops, he clarifies the matter in a very short style, beautifully and logically, while clarifying the matter with the example of himself and the bird in the cage. "A rebellion of poetry, rebellion, prayer, truth, and love!" I can't remember where I read this line about the poem. I once wrote it on a piece of paper. But I'm sure it's the same truth. Because the poet loves silently, prays silently, and quietly rebels. Otherwise, how would you react to such an unspoken, angry, rebellious rebellion about FREEDOM?

"Talent is a word, a sense of truth and sophistication. Truth is the father of poetry, the mother of beauty, and the word is its garment. A miracle of the soul. And poetry is a miracle of the soul. That is, the miracle of miracles is that Allah says that I created the two worlds for one soul" [8.P.26], says Jamal Kamal, a mature poet of our time. How wise these words are. Such miracles happen only when the God-given talent and heart unite. It would not be human nature to express it, to create divine miracles, even if there is a talent and there is no heart or there is no talent as a heart.

"Khosiyat is a creator who understands the infinity of perfection and understands that creation is a divine work," said the People's Poet of Uzbekistan Usmon Azim. Because of this, we think that his poems are very rich in divine melodies and divine thoughts. Let us return to the writings of the poet $U$. Azim: "... I have not read such heartfelt poems for a long time. Not everyone is fortunate enough to have a heart attack. Khosiyat has accomplished this difficult and inspiring task. She didn't look at the street looking for a subject. She felt with pure talent that the heart was an infinite subject. She realized that the poem consisted of a heart that turned into a drop of tears. Their feelings are real and very real. There is an inner violence in them," he said[7. B.3]. In the foreword to the poet's collection "Nojot". Because, as the poet herself said:

Men bir kun ulg'ayib qaytsam Vatanga!

Ustimda eskirib ketmasmi libos?![4. P.107].

Meaning:

When I grow up, I will return home one day! Isn't my dress worn out?!

- that is, the poet was really able to express very sincere feelings. In the above verses, he refers to a love that is not simply written in her views on the Motherland, but a divine and true love that no one can say, no one can imagine, no one can express. True, love is a very old feeling. Her image, tone, and expression are also very ancient. Just like in the stories, epics, novels created by our ancestors in the past. Of course, when it comes to antiquity and history, it is not difficult to imagine that over time, the clothes of both the homeland and the people will become obsolete, spilled and renewed. But the eternity of love, the eternity of love, is equal to the eternity of the feeling that is hidden, cared for, and cherished in the depths of the human heart. Such feelings are a never-ending, unforgettable concept that has become a value that is closely linked to human life. This is the concept of love! That is why she is a poet:

Qalbim bu olovga qorishar erib,

Erni quyosh bilan barobar etdi.

Jonim muhabbatni avaylayverib,

Ustimdagi libos eskirib ketdi. [3. P.87].

Meaning:

My heart melts in this fire,

It made the earth equal to the sun.

My soul cares for love,

My clothes are worn out. 
CURRENT RESEARCH JOURNAL OF PHILOLOGICAL SCIENCES 2(9): 123-

133, September 2021

DOI: https://doi.org/10.37547/philological-crjps-02-09-26

ISSN 2767-3758

(C)2021 Master Journals

Crossref doi

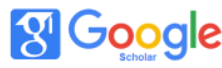

Accepted25 $5^{\text {th }}$ September, 2021 \& Published $30^{\text {th }}$ September, 2021

- she says. These lines refer not only to life, to the passing of life, to love, but also to man's eternal dreams, her purpose, her great love for his country and her people. The more the creator realizes the great concepts, the more she thinks about how great her figurative expression is, and of course, uses such lofty findings and metaphors. This idea also refers to the notion that times change, that everything changes and becomes obsolete with the passage of time, and that only emotions are eternal. After all, the author lived in love, not in clothes. Because the goal was to raise love and make it grow.

When we look at Khosiyat Rustamova's work, we see in her poems a heart that breathes, sometimes runs, sometimes flies, sometimes blooms in trees, and sometimes swells in buds. They tell of life, death, earth and sky, and most importantly, love of man, nature, homeland, love, soil, water. Helps to read, understand, listen, write, visualize and visualize. It artistically expresses the divine, philosophical, and social aspects of the life you see and live.

The peculiarity of the poet's style is that in it we come across examples of artistic means, special cases of style, beautiful poetic art:

Xayr,kunduz!!!

Salom, tun!

Uzr kamu ko'stiga.

Men qulab tushdim bugun

O’z soyamning ustiga. [3. P.39].

Meaning:

Good bye, day

Hello, night!

Sorry for the inconvenience.

I collapsed today

Over my own shadow.

In the passage above, we encounter one of the special cases of style, the compliment. As the poet says goodbye to the day and greets the night, he suddenly changes his mind, apologizes, compliments, and informs about his situation, creating a beautiful example of turning around.

Among the verbal arts in the literature are tajnis (word play), laffu nashr (collection and distribution), saj (rhyme in prose text) talmeh (use of historical names), satire, asking, urging, confrontation, return ( ruju'), cutting (qati'), metaphor, exaggeration, simile, adjective, animation. One of such poetic ornaments used by poets in classical literature was laffu nashr (collection) of words such as "flowers, nightingales", "orazing, zulfing", but today these cases are used in modern poetry, by discovering new form and content, and so on:

Bo'layin xuddi sen xohlagan kabi,

Bo'laklab tashlayin jonu tanimni.

Sochim, ko'zu qoshim,burun, yuz, labim-

Qaytadan terib chiq suyaklarimni.[3.P.119].

Meaning:

Be the way you want me to be

I'd like to have a shave.

Hair, eyebrows, nose, face, lips

Pick up my bones again

In this poem, the lines "My hair, my eyebrows, my nose, my face, my lips" and "Gather my bones again" stand out as a shining example of the verbal art of laffu nashr (collection and distribution). Talmeh art was also used effectively in the poet's work. Her poems, using the historical names of many Russian, German, Turkish, and Indian poets, create beautiful examples of the art of talmeh.

For example, in a poem dedicated to "Istanbul", which begins with "High buildings ...":

Devorda afisha... Bir qiz ko'ksi qon,

Cho'k tushib turibdi poyida san'at.

Sulton Ahmeddagi ming bitta do'kon,

Qadim Turkiyani sotish bilan band. [3. P.92].

Meaning:

A poster on the wall ... A girl's breast blood,

Art is sinking to the bottom.

One thousand and one shops in Sultan Ahmed,

Busy selling ancient Turkey.

Or, in the poem "Hanifa ayamga": 
CURRENT RESEARCH JOURNAL OF PHILOLOGICAL SCIENCES 2(9): 123-

133, September 2021

DOI: https://doi.org/10.37547/philological-crjps-02-09-26

ISSN 2767-3758

(C)2021 Master Journals

Crossref do

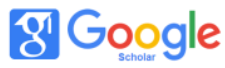

Accepted25 $5^{\text {th }}$ September, 2021 \& Published $30^{\text {th }}$ September, 2021

Hindcha kuy-qo'shiqlar chalg'itar elas,

Maftunkor qizlarning ko'ylagi-sari.

Va yana Tagordan olaman nafas-

Tirilar bolalik xotiralari. [3.P.75].

Meaning:

Indian songs are distracting,

Charming girls' jackets.

And again, I'll take a breath from Tagore

Living childhood memories.

In both of the above poems, using the names of historical figures from other countries, the poet delves deeper into the essence of his goals and makes effective use of the art of talmeh in revealing them. This art method is a way of ensuring the weight of thought in poetry, encouraging the perception of large poetic scenes in short lines.

Ignorance, asking (tajahuli arif). Did the poet hope to express his state and feelings clearly? bumidi? is that so is that so why so why is that and expresses the idea in a beautiful way. In a poem that begins, "Azizim":

Azizim, dunyoning bo'lgani shumi,

Hayot atalarmi shu dovu daska?

Eslayman, ruhimning tug'ilgan kuni-

Ancha yuksaklardan qaraydi pastga.

Dunyo kengga o'xshar.

Havo beadad,

Soya tashlab o'tar quyoshning aksi.

Orzum ushaldimi?

Murod-u maqsad-

Ko'rgan-ko'rishganim shumi hammasi? [6. P.106].

Meaning:

My dear, this is the world,

Is this the father of life?

I remember my soul's birthday-

It looks down from a great height.

The world seems wide.

The air is clear,

The reflection of the sun casting a shadow.

Did my dream come true?

Purpose and purpose

Is that all I've seen?
In the above lines, the poet describes life with a series of questions. Although he has a broader understanding of life, he tries to express his thoughts more broadly through the art of asking what it is and how it is, that is, tajahuli arif, without knowing himself. And it reveals the horrors of life more deeply.

Yashin tezligida uchdim - beqanot, Shunaqa bo'lar, deb yashash tilsimi. Azizim, ne kuyga solmadi hayot -

P.106]. Ruhimning ko'rinib turgan qismini?![6.

Meaning:

I flew at lightning speed - restless,

That's the decent thing to do, and it should end there.

My dear, what life did not sing -

The visible part of my soul?!

Of course, a person is in such a hurry that he does not even realize how fast his life has passed. But what tunes does this life not put a person in? In most cases, it makes a good person bad. When he is healthy, he is sick. When you are young, you grow old. It has an upright shape. Burro weakens his tongue. It whitens black hair and wrinkles clear and flat faces. All of this is manifested in the part of the body that is the visible part of the human soul. The poet says it all in one sentence. The following four are also good examples of the art of asking.

Gunohlarim ko'pmi shu qadar?

Yo umidlar bo'lganmi barbod?

Jinoyati og'ir mahbusday

Meni ushlab turibdi hayot. [3. P.11].

Meaning:

Am I guilty of so many sins?

Or did the hopes fail?

It's like a serious prisoner

Life holds me back.

The art of persuasion is also one of the most enduring ornaments of poetry. The poet makes effective use of invitations, invitations, and urges to 
CURRENT RESEARCH JOURNAL OF PHILOLOGICAL SCIENCES 2(9): 123-

133, September 2021

DOI: https://doi.org/10.37547/philological-crjps-02-09-26

ISSN 2767-3758

(C)2021 Master Journals

Crossref doi

81 Google

Accepted25th September, 2021 \& Published $30^{\text {th }}$ September, 2021

infect the reader with waves of emotion.

Xo'rligingiz kelmaydimi

Uyulib tursam,

Bir burchakka yig'ib qo'ysam

Jismu jonimni.

Meni ko'mar shu tuproqning

Ustida kulsam -

Hayot hali o'lmasimdan

Olsa borimni...

Ketasizmi tunlarimdan

Burilib tongga,

Qadamingiz uyingizga

Etganicha to.

Faqat bir so'z aytib keting

Ikki jahonga -

Men hayotning qaerida

Qilganman xato?

Meaning:

Don't you want to be humiliated?

When I stay sad,

My body is my soul

If I put it in a corner.

Of this soil that buried me

I laughed over it.

Life before I die

If he takes what I have

Will you leave my nights?

Turning to dawn,

Your step home

Etganicha to.

Just say the word

Two worlds -

Where am I in life

Did I make a mistake?

"Is it time?" In the first four verses of the above poem, which begins with This is a testament to the poet's skill in applying the art of special moments in poetry.

Also, in poetry, the state of masterfully combining opposing ideas is called resistance, another characteristic of the style. This phenomenon is often reflected in the work of the poet:

Yo tangrim. Sen menga kuch ber,

Ber chidam -

Xuddi daraxtlarday ko'tarayin qad.

Ichimga qor yoig'ib turganida ham,

Men kulib turishim kerak hamma vaqt. [

3. P.4].

Meaning:

Oh my God. You give me strength,

Hold on -

I will rise like a tree.

Even when it snows inside me,

I have to laugh all the time.

In the above poem, the meaning of weakness in the first line is opposed to the meaning of strength in the second line. In the third row; "Even when it's snowing," is the opposite of "I have to laugh all the time." This is also used as a good example of resistance. In one of her poems below:

Men Senga oq so'zlar

Uzatsam yonib -

Ko'zlaring gapirar

Qop-qora rangda! - deydi.

Meaning:

I give you white words

When I turn on the light

Your eyes speak

In black! They say.

In this poem, too, the poet uses the art of resistance again, tying lines meaning white eyes to white words. Art works, in turn, serve as a creative detail in promoting the poet's goals and ideas.

There is also the art of cutting (qati') in poetry, in which the poet suddenly interrupts when he realizes that it is useless to speak in order to express some feelings and thoughts. She tries to express emotionally that he is unable to speak.

In a poem beginning with "Boshqa hech gapim yo'q...":

Dengizday chayqalib turasan karaxt, Xayoling bir nafas qolar sovuqda. Jonim, mendan Senga qolgani faqat, 
CURRENT RESEARCH JOURNAL OF PHILOLOGICAL SCIENCES 2(9): 123-

133, September 2021

DOI: https://doi.org/10.37547/philological-crjps-02-09-26

ISSN 2767-3758

(C)2021 Master Journals

Crossref doi

gil Google

Accepted25th September, 2021 \& Published $30^{\text {th }}$ September, 2021

Faqat uchta nuqta...

Faqat uch... nuqta. [3. P.98].

Meaning:

You stagger like the sea,

Your mind stays cold for a breath.

My soul, all that is left of you to me,

Only three points ...

Only three ... points.

-she says. The poet already has a great wealth, a high spiritual heritage and a great art of speech to leave. But she is not in a hurry to put it into words. She can put all his thoughts into these three points and cut out the word and create the art of cutting (qati'). Only the poet knows that the three points are continuous, that there are so many ideas in her heart, and that they have silenced the poet's language. It's a question, it's a riddle. Encourages the student to understand.

\section{Conclusion}

In short, "There is another world that is more beautiful and purer than the world we know. This is the world of poetry. The world of poetry. It's like leaving this world without realizing it and living without it." This is stated in the annotation of Khosiyat Rustamova's collection of poems "August". Indeed, every poet, in the world of her creation, in the world of poetry, embodies her whole being, her inner world, her dreams, her goals, her love, her faith, her honesty. In other words, her spiritual and enlightenment views are vivid. These aspects determine the poet's spiritual identity and serve as the basis for her creative originality.

\section{REFERENCES}

1. Decree of the President of the Republic of Uzbekistan dated February 7, 2017 "On the Strategy of further development of the Republic of Uzbekistan".
2. Mirziyoev Sh. M. We will build our great future together with our brave and noble people. Tashkent; Uzbekistan.2017. - P. 488.

3. Erkin Vahidov Poet. - Tashkent: Young Guard.1987.

4. Khosiyat Rustamova Occupation.-Tashkent: Akademnashr.2011.

5. Khosiyat Rustamova August.-Tashkent: New century generation.2008.

6. Ozod Sharafiddinov (translations) World writers on literature.-Tashkent: Spirituality. 2010.

7. Khosiyat Rustamova 40: 0.-Tashkent: Istiqlol. 2011.

8. Khosiyat Rustamova "Hope".-Tashkent: Spirituality.2003.

9. Umid Ali "Konilga sayr". Tashkent: Cholpon Publishing House.2017.

10. Matyokubov A. Life and art. -Tashkent: G. Gulom Publishing House of Literature and Art, 1985. -В.13-14.

11. Муслихиддин, М. К. (2021). THE VIRTUE OF THE WORD. ALISHER NAVOIY XALQARO JURNALI, 1(1).

12. Muhiddinov, M. (2005). The perfect man is the ideal of literature. Tashkent: Yangi asr avlodi, 206.

13. MUKHIDDINOV, M., SULAYMONOV, I., KHASANOVA, M., ASLANOVA, K., \& SHOMURODOVA, S. (2021). Ode genre and ideological-artistic features of erkin vahidov's odes. Journal of Contemporary Issues in Business and Government, 27(3), 1317-1323.

14. Mukhitdinova N. (2021). Artistic improvement of Alisher Navoi traditions in Ghazi and Sadoi poetry. LAP LAMBERT Akademic publishing, $104 \mathrm{p}$.

15. Muslihiddinovna, M. N., \& Fatkhiddinovna, K. S. (2019). The comparative character analysis of farhad and majnun in epic poems by alisher navai. Test Engineering and Management, 81(11-12), 4198-4206. 
CURRENT RESEARCH JOURNAL OF PHILOLOGICAL SCIENCES 2(9): 123-

133, September 2021

DOI: https://doi.org/10.37547/philological-crjps-02-09-26

ISSN 2767-3758

(C)2021 Master Journals

Crossref doi 81 Google

Accepted25 $5^{\text {th }}$ September, 2021 \& Published 30 ${ }^{\text {th }}$ September, 2021

16. Mukhitdinova N. M. (2017). Traditions of western poetry in Sadoi's works. International Journal of Science and Research, P: 922-924

17. Mukhitdinova, N. M. (2016). TRADITIONS OF BOBORAKHIM MASHRAB IN CREATIVE ACTIVITY OF KHOZHANAZAR KHUVAYDO. Международный научно-исследовательский журнал, (4 (46) Part 4), 61-64. 